allied interests to dominate regulatory activities in the EC. As and when the agency comes into being in or around 1993 (the site is not yet decided, but it could be in the Netherlands) care will have to be taken that its membership and working practices are as open and representative of informed public interests as possible.

It would be wrong to overstate, however, the risk of medicine safety standards being undermined by future EC arrangements for licensing. As suggested above a more potent threat to community wellbeing might stem from a weakening of medical control of public health care prescribing coupled with increasing pressures on consumers to pay directly for their medicines. Should this take place there will be a risk of depriving poorer people in Europe of access to effective care. This would be counterproductive in both social and financial terms, in that it could cause otherwise preventable ill health while undermining consumer confidence in existing provisions.

Those in government, the professions, and the pharmaceutical industry who are at present involved in lobbying to determine the structure of the future unified EC market should be aware of such dangers. ${ }^{\text {is }}$ As is shown by the United Kingdom's record of keeping drug industry promotion spending down to about half the percentage of domestic turnover in countries such as France and Germany, there may be opportunities for reforms across the EC. But it would be foolhardy to interfere too quickly or too radically in structures that over the past 40 to 50 years have served public interests well. Compared, say, with eastern Europe's past record of low innovation and inadequate prescriber and patient access to drugs, that of the West is one thankfully to be preserved.

It is important to maintain the optimal amount of prescriber freedom and affordable access to medicines for all patients. Greater sensitivity to the price of medicines throughout the EC should not be gained at the expense of impairing society's ability to value effective treatment for everyone.

I Sauer F. The European community's pharmaceutical policy. Brussels: Commission of the European Communities Directorate General for Internal Market and Industrial Affairs, 1990.

2 Barings Corporate Finance Healthcare. The implications for the medical device and pharmaceutical industries of the EC's 1992 programme. London: Baring Brothers, 1991.

3 Burstall ML. 1992 and the regulation of the pharmaceutical industry. London: Institute of Economic Affairs, Health and Welfare Unit, 1990.

4 Association of the British Pharmaceutical Industry. Pharma facts and figures. London: ABPI, 1990.

5 Organisation for Economic Cooperation and Development. Health care systems in transition. Paris: OECD, 1990.

6 Taylor D, Maynard A. Medicines, the NHS and Europe. London and York: King's Fund Institute and Centre for Health Economics, 1990.

7 Smith T. Limited lists of drugs: lessons from abroad. BMF 1985;290:532-4.

8 O'Brien B. Patterns of European diagnoses and prescribing. London: Office of Health Economics, 1984

9 Payer L. Medicine and culture. London: Goallancz, 1989.

10 Shearson Lehman Brothers. Pharma pipelines. London: Shearson Lehman Brothers, 1991.

11 Poll looks at French tranquilliser use. Financial Times Pharmaceutical Business News 1991;157:2.

12 Thomas LG. Spare the rod and spoil the industry. New York: Columbia University, 1989.

13 European drug regulation-anti-protectionism or consumer protection? (editorial). Lancet 1991;337:1571-2.

14 Griffin JP. Will the British Committee on Safety of Medicines be obsolete in 1993? I R Coll Physicians 1991;25:44.

15 Tross J. In: Thumbs down for commission action on pricing. Scrip 1991;1629: 4-5.

16 Schieber GJ, Poullier JP. International health spending: issues and trends. Health Affairs 1991; Spring:106-16.

17 Diener F. Pharmazeutische Zeitung 1990;40:2631-8.

\title{
Health and the Environment
}

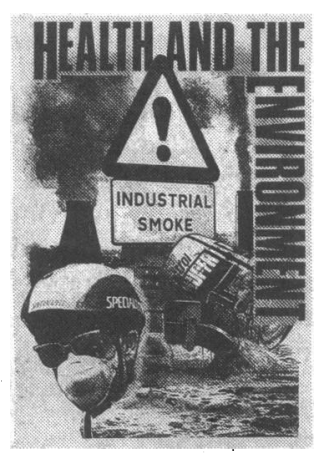

\section{Swimming - the hazards of taking a dip}

\author{
Alison Walker
}

In summer it [the sewage] causes a visible brown buoyant stain extending from the outfall pipe and spreading its way along the bays as it is brought in by the incoming tide.

Sons of Neptune bathing club, Scarborough

Scarborough is not the only resort where holidaymakers have to contend with sewage in the sea. Short Victorian outfall pipes still discharge sewage from coastal towns all round Britain. Leaving Britain's shores and holidaying in the Mediterranean provides no escape as the beaches there are no better. The picture, however, is changing. The longheld belief that the sea can absorb, dilute, and disperse everything discharged into it is now seen as wishful thinking and is no longer accepted. Throughout Europe resorts are starting to be cleaned up as European politicians begin to take notice of public opinion and growing scientific evidence incriminating contaminated sea water as the cause of symptoms in holidaymakers.

British Medical Journal, London WC1H 9JR

Alison Walker, MRCP, former editorial registrar

Correspondence to: Department of Paediatrics, St Mary's Hospital, London W2 INY.

$B M \mathcal{F} 1992 ; 304: 242-5$

\section{Health risks from swimming in seawater}

Until a few years ago the British government relied on research from the 1950s to form the cornerstone of its policy on bathing water. The research was performed by the Public Health Laboratory Service and looked retrospectively at poliomyelitis (a serious problem at that time) and enteric fever in sea bathers. The conclusions were reported jointly by the laboratory service and the Medical Research Council and showed that, with the exception of a few heavily polluted waters, the risk to public health from swimming in sea water contaminated by sewage could, for all practical purposes, be ignored. ${ }^{2}$

Things have moved on since the 1950s, and although the laboratory service's studies were carefully conducted, they are now seen to be limited by the techniques of the time. The risk of swimming in heavily polluted water remains undisputed and carries with it the risk of contracting infections such as typhoid, shigellosis, leptospirosis, and hepatitis A. More contentious, however, is the possible link between minor infections and swimming in sea water that is only moderately contaminated.

Establishing a link between minor illnesses such as gastroenteritis and ear, nose, and throat infections and swimming in polluted sea water is extremely difficult because these conditions are so common and may have various causes. Some headway has been made from large epidemiological studies which have compared the symptoms of swimmers with those of people who stayed out of the water.

One of the first studies to show a relation between sea bathing and minor symptoms was a prospective cohort study carried out in the 1970 s by the United States Environmental Protection Agency. ${ }^{3}$ The work was performed by Victor Cabelli in three different resorts-New York City, Lake Pontchartrain, Louisiana, and Boston-over five years. Altogether more than 25000 people took part. Those bathing were 


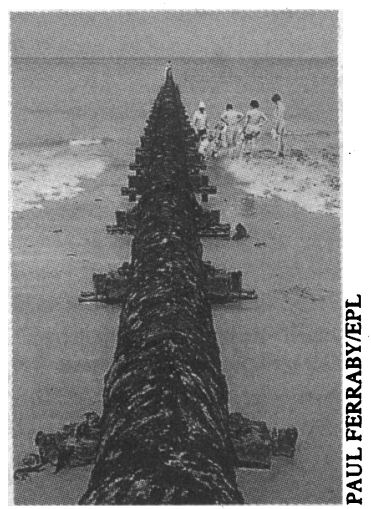

The sea cannot absorb everything discharged into it questioned about symptoms acquired after swimming in the sea, and members of their family and friends who did not swim were used as controls. Samples of seawater were also taken and tested for levels of contamination. Cabelli's results showed a relation between swimming, gastrointestinal symptoms, and the quality of the sea water. This study, like most later studies, had to use self reporting of symptoms without any medical check ups or clinical tests to confirm these symptoms. In a pilot study Cabelli had found that volunteers could not be persuaded to submit to a free medical examination.

Cabelli's work spawned other studies around the world from researchers attempting to obtain repeatable and reliable quantifiable data. Although repeated with only varying degrees of success, Cabelli's method of using a prospective cohort study with self reported symptoms has since been endorsed by the World Health Organisation and United Nations environmental programme.

\section{BRITISH STUDIES}

In Britain the Department of the Environment, cofunded by the National Rivers Authority and the Welsh Office, commissioned its own research in 1989 to assess the risks associated with swimming in polluted sea water. Two types of study were performed-a beach study similar to that used by Cabelli (but with better statistical analysis) and their own healthy volunteer cohort study, which included medical check ups and clinical tests to confirm the results of reported symptoms. The work was headed by $\mathrm{Dr}$ Edmond Pike, principal microbiologist at the Water Research Centre, in conjunction with the Robens Institute at the University of Surrey and St David's University College, Lampeter.

Pilot studies were first carried out at Langland Bay in West Glamorgan to assess the two methods. ${ }^{4}$ In the beach survey more than 4000 people on the beach during 20 days in August were interviewed about perceived symptoms and bathing histories. A week later nearly 800 of them were telephoned to obtain further information about any symptoms. Intensive microbiological sampling of the water was carried out on the days of the beach survey. The second method, the cohort study, recruited just over 270 people. They first underwent clinical tests before bathing (throat and ear swabs and faecal samples were taken) and then were interviewed for symptoms of ill health on the day they went swimming. Finally, the interviews and clinical tests were repeated three days after exposure. A further postal interview and faecal sample were obtained four weeks after exposure.

Results from both phases of the study at Langland Bay showed a higher incidence of ear and throat symptoms among those who went into the sea. The studies were not designed to produce statistically valid results but to confirm the effectiveness of the methods. Nevertheless, some significant results did emerge. The beach survey, for example, found that 1 in 13 bathers reported symptoms compared with only 1 in 32 nonbathers. Furthermore, the study indicated that the rate of reporting one or more symptoms was related to the degree of contact with the water. The results of the cohort survey did not show any correlation between reported symptoms and the results of the medical check up or analysis of the throat, ear, and nasal swabs and faecal samples taken. This part of the study, however, said Dr Pike, was hampered by having a big drop out rate between volunteering and the day of exposure.

The Department of the Environment's report of the Langland Bay studies was presented to the House of Commons Environment Committee in 1990 . The committee had been given the task of investigating the pollution of Britain's beaches. 'In its conclusion it was critical of the lack of interest shown by past governments, saying that Britain's reputation abroad had been damaged. It went on to recommend that the Water Research Centre carry out further larger studies in order to be able to quantify the level of risk to bathers. These were performed in 1990 at Ramsgate Sands in Kent, where a beach survey was carried out, and Moreton Beach in Merseyside, where a healthy volunteer cohort study was performed. These studies formed the first stage of a definitive study to establish a relation between microbiological quality of sea water and the risks to health of bathers.

Both the Ramsgate Sands and the Moreton Beach studies yielded significant conclusions despite their small sample sizes. ${ }^{5}$ At both Moreton and Ramsgate bathers were more likely to suffer from minor infections than non-bathers, and a dose related risk was established-waders experiencing fewer symptoms than swimmers, who in turn were less ill than surfers and divers. The success of these studies has led to extension of the work to include eight beaches in 1991 and 19.92 and interviews with over 16000 holiday makers. ${ }^{6}$

One of the main findings of the study at Ramsgate was the significant association between bathing in the sea and gastrointestinal symptoms. ${ }^{7}$ The sea water at Ramsgate contains a high level of faecal pollution and, of some political concern, has failed the European Commission bathing water directive standards for two years running.

\section{European Commission bathing water directive}

The European Commission bathing water directive was introduced in 1975. It defines standards for beaches authorised for bathing or where bathing is

\section{Swịmming inland}

No inland waters are designated for bathing. The only regular monitoring that takes place in them is of chemical and not microbiological parameters. Although there were no statutory requirements for the National Rivers Authority to test inland waters, monitoring does take place in some non-designated inland waters used for recreational purposes. ${ }^{8}$ In general, river waters do not meet the coliform criteria of the European Commission bathing water directive because of the presence of treated sewage effluents and other agricultural inputs. Many of the inland still waters and abandoned docks, however, are of high bacteriological quality.

An old problem has recently re-emerged in rivers, estuaries, and the sea-that of toxins released by blooms of certain cyanobacteria (blue green algae). The death of some dogs in 1989 who drank contaminated water from Rutland reservoir, brought the subject back on to the front page. An increased nutrient load of phosphates and nitrates from sewage works, together with the long hot summers of recent years, is believed to have promoted the excessive growth of cyanobacteria. For the past two years the rivers authority has been monitoring waters for algae. Of the $\mathbf{6 8 0}$ tested, nearly $\mathbf{6 0 0}$ were found to contain cyanobacteria but only 170 of them contained high densities of bacteria. Furthermore, not all cyanobacteria release toxins-and predicting whether a particular bloom will be toxic or not is impossible.9 Those that are, produce three types of toxin-neurotoxins, hepatotoxins, and contact irritants. That they can be lethal has been shown by the death of animals, but more research is needed before the risks can be better understood. At present the best approach is prevention, as emphasised in the authority's report on toxic cyanobacteria ${ }^{10}$ and avoidance of water containing algal scum. 
"not prohibited and is traditionally practised by large numbers of bathers." All European Community members had 10 years in which to bring their beaches up to scratch. Only 27 beaches were initially identified by the British government as affected by the directive, which, unrealistically, ignored resorts like Brighton and Blackpool. In 1987, more than 10 years later, the government conceded and a further 350 beaches were included. In 1991, 453 of beaches were identified as bathing waters in Britain. No bathing waters have been designated inland (box).

The directive defines physical, chemical, and microbiological parameters for bathing water based on the results of fortnightly samples taken during the bathing seasons from April to September. The tests are carried out in Britain by the National Rivers Authority, reporting to the Department of the Environment. ${ }^{8}$ Table I summarises the microbiological standards. ${ }^{11}$ The recent results have shown that $76 \%$ of Britain's beaches complied with the directive in 1991 compared with $77 \%$ in 1990 . The figure for 1990 was below the figure for other European countries in that year, notably the Netherlands $(90 \%)$, France $(86 \%)$, and Ireland $(85 \%) .{ }^{12}$ Nevertheless, the government has set in motion an improvement programme costing $£ 2$ bn to make sure that virtually all bathing waters will be up to standard by the end of 1995 . This has necessitated a review by undertakers of sewage treatment before discharge into the sea.

TABLE I-Microbiological standards of European Community bathing water directive ( $95 \%$ of samples should contain these levels ${ }^{\prime \prime}$ )

\begin{tabular}{lccc}
\hline & Guide level & $\begin{array}{c}\text { Mandatory } \\
\text { level }\end{array}$ & $\begin{array}{c}\text { Minimum sampling } \\
\text { frequency }\end{array}$ \\
\hline Total coliforms $/ 100 \mathrm{ml}$ & 500 & 10000 & $\begin{array}{c}\text { Fortnightly } \\
\text { Fortnightly }\end{array}$ \\
$\begin{array}{l}\text { Faecal coliforms } / 100 \mathrm{ml} \\
\text { Faecal streptococi } / 100 \mathrm{ml}\end{array}$ & 100 & 2000 & $\begin{array}{c}\text { Discretionary } \\
\text { Discretionary }\end{array}$ \\
$\begin{array}{l}\text { Salmonella/l } \\
\text { Enteroviruses (plaque } \\
\text { forming units/101) }\end{array}$ & 0 & 0 & Discretionary \\
\hline
\end{tabular}

\section{Sewage treatment}

Up until 1990 most sewage from coastal areas in Britain was discharged straight into the sea with the only treatment, if any, being that of screening for the removal of gross solids, or maceration. ${ }^{8}$ Short and long sea outfall pipes and stormwater overflows are the three main routes by which sewage is discharged directly into the sea. In March 1990 it was announced that a minimum of primary treatment (box) would be required before sewage effluent was discharged into the sea. This has now been introduced as another European Commission directive, the municipal waste water directive, which was passed in April 1991 and now applies to all member states.

Even once the new directive has been fully implemented and sewage effluent is treated before being discharged into the sea, the possibility of some contamination of seawater remains. Primary sewage

Typical survival characteristics of faecal bacteria and human enteric viruses in seawater"

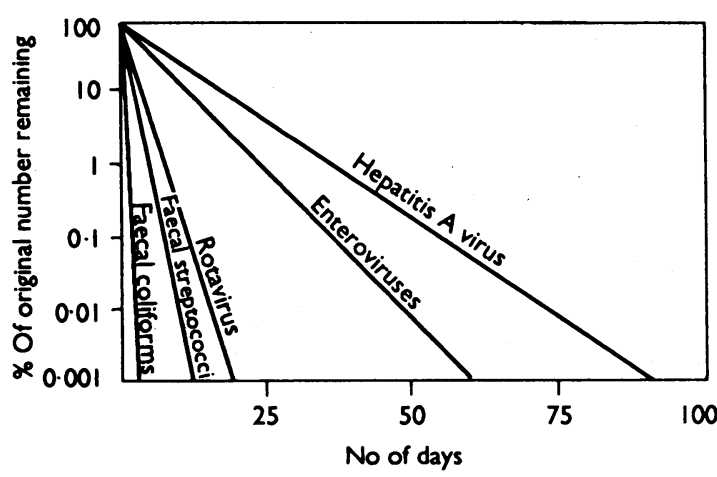

\section{Sewage treatment}

Nearly $90 \%$ of Britains sewage is treated at land based sewage treatment works, which discharge effluent into rivers, estuaries, and eventually the sea. ${ }^{13}$ Ten per cent is discharged directly into the sea, and the remainder is treated in septic tanks.

Preliminary treatment-Paper, cloth, sticks, and other objects are removed by screens. Grit is allowed to settle in special tanks.

Primary treatment-Solid matter is left to settle to the bottom of settlement tanks as sludge. This takes from two to six hours.

Secondary treatment-Biological treatment with micro-organisms is used to encourage the oxidation of organic matter. The resulting liquid passes through a further settlement tank, after which at least $95 \%$ of its organic load will have been removed. If of a specified standard the effluent can be discharged straight into a river, or it can receive further treatment.

Tertiary treatment-This produces a clear liquid containing very little organic matter but a large quantity of faecal and other bacteria. These die off naturally and rapidly in the rivers and sea. Possible forms of tertiary treatment include pebble bed clarifiers, irrigation over grassland, sand filtration, and microstraining through fine steel fabric.

Sludge treatment-Sludge may be pumped directly from primary tanks into the sea if this is practicable. If not it undergoes biological or chemical treatment to remove pathogens or excess water, or both, and to reduce odour. This changes it from a foul brew to a brown sludge with an earthy odour. It may be dried into a solid cake if it is to be transported by land or sea any distance. Disposal of sludge at sea is to be phased out by 1998. Alternative disposal sites are on farmland (after treatment to reduce pathogens) in landfill sites, or by incineration.

treatment will remove only $30-80 \%$ of pathogens, according to David Wheeler, microbiologist and senior research fellow at the Robens Institute at Surrey University. Full secondary treatment in a well operated plant can remove at least $99 \%$ of enteric bacteria, including salmonella, and $90 \%$ of enteroviruses - the remainder finding their way into the sea. The new directive does not make secondary treatment obligatory - primary treatment is acceptable if the receiving waters can accept the effluent without environmental damage-although the new treatment schemes will be designed so that the sea water meets the standards of the bathing water directive. Some debate, however, still remains over the microbiological parameters in the directive, which many authorities consider need updating.

\section{At sea over standards}

Most countries interpret the standards in the bathing water directive to their own liking. According to the House of Commons Environment Committee, a tacit agreement exists between all members of the European Community, to ignore the standards for enterovirus and salmonella as the zero levels required are unobtainable. ${ }^{1}$ The only mandatory standards are for total and faecal coliforms, which are used as indicators of contamination of the sea water by sewage.

As evidence linking minor illnesses with swimming in the sea mounts up, the importance of testing for viruses increases. Not only are viruses potentially responsible for many of the minor illnesses associated with seabathing but they decay at a slower rate in the sea than bacteria and can cause infection at much lower doses. It may be that faecal streptococci, which have a longer survival time than coliforms, will emerge as a 


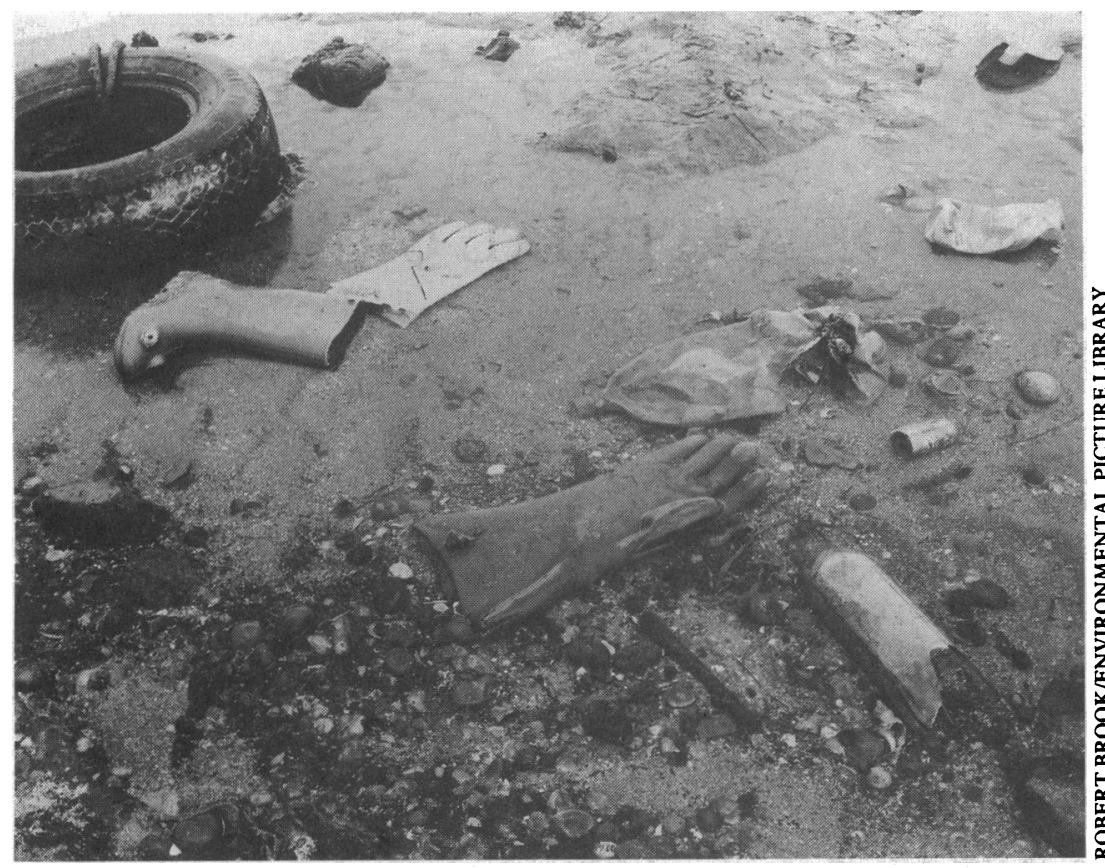

If a beach looks filthy, don't swim in the sea

better indicator of sewage contamination in future (figure).

In the United States a dose response curve quantifying degree of risk in terms of degree of exposure to pollution has been drawn up by the Environmental Protection Agency, based on the results of Cabelli's research. The United States is altogether more interventionist than Britain over its policy for coastal bathing. Beaches are actually closed when a certain number of samples fail to reach the predetermined standard. ${ }^{1}$ One of the difficulties with closure is that beaches often fail because storms disperse sewage onshore. The water sampled from a beach taken at such a time will fail-even though no one would be tempted to bathe. The United States Environmental Protection Agency has not yet resolved the problem of when to open the beach again. The decision of whether or not the sea is too polluted to swim in is still left up to individuals in Britain - but increasingly they are being helped in their decision by the use of beach quides.

\section{Beach guides}

Beach guides have flourished in the past few years and the public is now faced with a seemingly ever increasing amount of information on which to base the decision whether to swim.

The local authority guide recommended by the Department of the Environment has attempted to provide comprehensive information to the public and not simply regurgitate the results of tests carried out by the National Rivers Authority. It provides some explanation about the quality of the bathing water by dividing beaches into three categories according to the quality of the sea water-excellent water quality (complying with the European Community guideline standards), good quality (complying with the mandatory standards), and poor quality (those which fail both the previous tests). But a survey carried out by the Marine Conservation Society earlier this year found that where the water was of poor quality the local authority was not interested in publicising any results.
The society believes that compulsory guides are the only way to make the local authority scheme work.

The Marine Cönservation Society's own guide, The Good Beach Guide (Ebury Press), is also based on the European Commission directive and, has looked at more than 450 beaches in Britain. Most passed or marginally failed the mandatory guidelines, but only a few get its full four star rating for passing all tests at the guideline level.

The European Blue Flag Campaign was started in 1987 as part of the European Year of the Environment. In Britain it is supported by the Tidy Britain Group and the English Tourist Board with further help from the Department of the Environment, the National Rivers Authority, and the local authorities. The award is given annually and is valid for only one year. It requires compliance not only with water quality, as defined by the bathing water directive, but with the standard of the facilities on the beach, including cleanliness, provision of toilets, and parking. Last year 35 beaches were awarded a blue flag. Table II shows the results for Europe in 1991. There has been concern that, as water quality parameters and values vary from country to country, the awarding of blue flags to beaches may not be on a strictly comparable basis. ${ }^{8}$

Golden starfish awards are related to the blue flag scheme and are being piloted in Britain and Greece. They are awarded to beautiful remote beaches which cannot satisfy the blue flag criteria because they are too isolated and little used. Golden starfish awards were given to 13 beaches in Britain in 1991.

\section{Conclusion}

Swimming in the sea is the most natural of recreations. It would be a sad day if its benefits were outweighed by the risk of becoming ill. Research is still growing, but the links between gastrointestinal and upper respiratory symptoms and swimming in sea water contaminated by sewage are now irrefutable. The recovery programme for beaches is long overdue, but at least some action is at last being taken. But before all beaches can be deemed safe from pollution, a commonsense approach is probably the most sensible -if the water looks filthy it would be unwise to swim in it. If all else fails join the crowds on the beaches with a blue flag, an "excellent" rating from the local authority, or a four star award from the Good Beach Guide and avoid the hazards of taking a dip.

I am grateful to Dr Edmond Pike for his help in compiling this article. 1 House of Commons Environment Committee. Pollution of beaches: fourth
report. London: HMSO, 1990.

2 Public Health Laboratory Service. Sewage contamination of coastal bathing waters in England and Wales: a bacteriological and epidemiological study. f Hygiene 1959;57:435-72.

3 Cabelli VJ, Dufour AP, McCabe LJ, Levin MA. Swimming-associated gastroenteritis and water quality. Am f Epidemiol 1982;115:606-16.

4 Pike EB. Phase 1 pilot study at Langland Bay. London: Water Research Centre, 1990. (Department of Environment report 2518-M(P).)

5 Pike EB. Health effects of sea bathing. Phase II studies at Ramsgate and Moreton, 1990. London: Water Research Centre, 1991. (Department of Environment 1990. London: Water

6 Morris J. Sea survey continues. Water Bulletin 1991;465:7.

7 Balarajan R, Raleigh VS, Yuen P, Wheeler D, Machin D, Cartwright R. Health risks associated with bathing in sea water. $B M \mathcal{J}$ 1991;303:144-5.

Health risks associated with bathing in sea water. BMF 1991;303:144-5.
National Rivers Authority. Bathing water quality in England and Wales -1990. 8 National Rivers Authority.
Bristol: NRA, 1991.

9 Dunlop JM. Blooming algae. BMF 1991;302:671-2.

10 National Rivers Authority. Toxic blue green algae. London: NRA, 1990

11 Wheeler D. On the beach. Lab Practice 1990;39:19-24.

12 Water Services Association. Water information. Wastewater discharges to sea. London: Water Services Association, 1991.

13 Hall C. Running water. London: Robertson McCarta, 1990. 